biologic DMARD was allowed) were enrolled. The primary endpoint was the $\%$ of pts achieving the minimal clinically important difference (MCID; improvement of $\geq 0.22$ compared to baseline [BL]) in the Health Assessment Questionnaire Disability Index (HAQ-DI) at wk 78. Non-responder imputation (NRI) was used to account for the missing values. Secondary clinical parameters included $\%$ of pts achieving MCID in HAQ-DI at wks 24 and 52 and changes in the 28-joint DAS based on CRP (DAS28(CRP)), Simplified Disease Activity Index (SDAI), and Clinical Disease Activity Index (CDAl) at wks 24, 52, and 78 vs BL. Pts were categorized based on their participation in the PSP: ever (PSP users) vs never (PSP non-users) and outcomes were compared after adjusting for corresponding $B L$ values.

Results: Overall, the primary endpoint, percentage of pts achieving the MCID for HAQ-DI, was achieved by $72.1 \%$ (as observed) and $42.8 \%$ (NRI) of pts at week 78 with the percentage of pts achieving the MCID for HAQ-DI significantly higher in PSP users vs PSP non-users (48.1\% vs $37.8 \%$ [NRI]; $P<0.001)$. From 1,025 pts, $48.7 \%$ pts were PSP users (BL: mean age, 54.3 years (y); \% female, $77.1 \%$; mean RA duration, 7.8 y; mean HAQ-DI, 1.5; mean DAS28(CRP), 5.3; mean SDAI, 35.6; mean CDAI, 33.3; $17.8 \%$ pts had received prior biologic DMARD. Significant changes $(P \leq 0.05)$ from $\mathrm{BL}$ to wk 78 were observed for pts using the PSP vs PSP non-users in HAQ-DI (0.53 vs 0.39$)$, DAS28(CRP) ( -2.33 vs $-1.97)$, SDAl ( -24.5 vs -19.8$)$, and CDAl ( -22.66 vs -18.55$)$ scores (Figure). Study discontinuation rates were significantly $(P<0.001)$ lower among PSP-users vs PSP non- users ( $25.5 \%$ vs $41.6 \%)$. Reasons for discontinuations are listed in the Table.

Figure: Changes from baseline in DAS28 (CRP) (A), SDAI (B), CDAI (C), and HAQ-DI (D) over time between PSP users and PSP non-users.
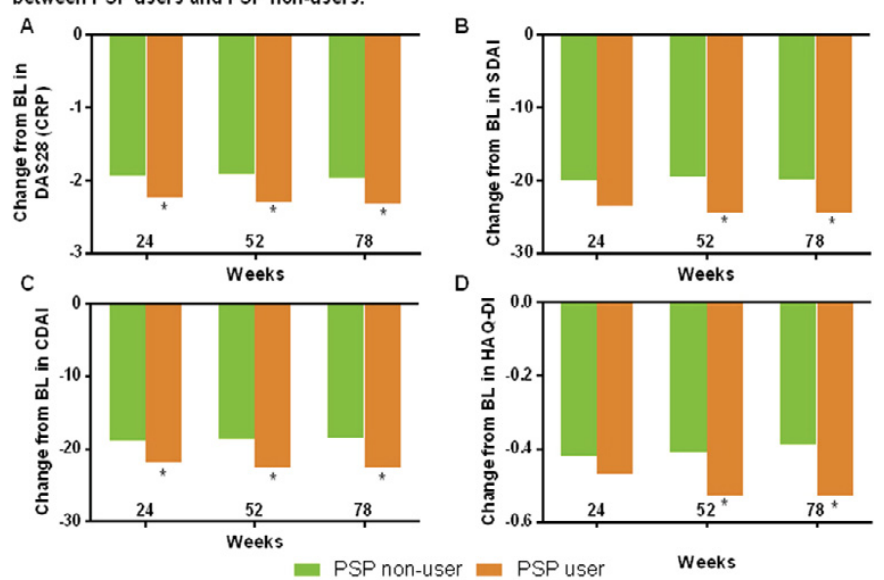

'sigrificartly ditterent between $P S P$ users and PSP non-1sers $P<0.05$ ) Data represented by LOCF imputdion for intertito treast pcopulation.

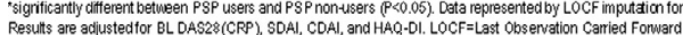

Table: All reasons for study discontinuation by PSP utilization category

\begin{tabular}{|l|c|c|c|}
\hline Subject Dispos ition & $\begin{array}{c}\text { All Patients } \\
\mathrm{N}=1025\end{array}$ & $\begin{array}{c}\text { PSP user } \\
\mathrm{N}=499\end{array}$ & $\begin{array}{c}\text { PSP non-user } \\
\mathrm{N}=526\end{array}$ \\
\hline Discontinued (\%) & $\mathbf{3 4 6}(33.8)$ & $\mathbf{1 2 7}(25.5)$ & $\mathbf{2 1 9 ( 4 1 . 9 )}$ \\
\hline Adverse event & $52(5.1)$ & $22(4.4)$ & $30(5.7)$ \\
\hline Withdrew consent & $37(3.6)$ & $13(2.6)$ & $24(4.6)$ \\
\hline Lost to follow-up & $46(4.5)$ & $17(3.4)$ & $29(5.5)$ \\
\hline Serious adverse events & $24(2.3)$ & $10(2.0)$ & $14(2.7)$ \\
\hline Lack of efficacy & $168(16.4)$ & $66(13.2)$ & $102(19.4)$ \\
\hline Other & $51(5.0)$ & $16(3.2)$ & $35(6.7)$ \\
\hline
\end{tabular}

Conclusions: The final study results showed that, in pts with moderate to severe RA who initiated ADA, significantly better improvement in functional and clinical outcomes was achieved in the PSP users vs the PSP non-users. Improvements were achieved at early timepoints and continued to increase throughout the study. Acknowledgements: AbbVie funded the study and the analysis, and approved the abstract for submission. Medical writing assistance was provided by Gaurav Patki, PhD and Benjamin Wolfe, PhD from AbbVie.

Disclosure of Interest: F. Van den Bosch Consultant for: AbbVie, Celgene, Janssen, Pfizer, and UCB, Speakers bureau: AbbVie, Celgene, Janssen, Pfizer, and UCB, A. Ostor Consultant for: Roche, Chugai, MSD, AbbVie, Pfizer, Novartis, Napp, and BMS, S. Wassenberg Consultant for: AbbVie, Celgene, Novartis, Pfizer, MSD, Lilly, Janssen and UCB, Speakers bureau: AbbVie, Celgene, Novartis, Pfizer, MSD, Lilly, Janssen and UCB, J. K. Anderson Shareholder of: AbbVie, Employee of: AbbVie, N. Chen Shareholder of: AbbVie, Employee of: AbbVie, C. Wang Shareholder of: AbbVie, Employee of: AbbVie, V. Garg Shareholder of: AbbVie, Employee of: AbbVie, J. Kalabic Shareholder of: AbbVie, Employee of: AbbVie DOI: 10.1136/annrheumdis-2017-eular.1876

\section{SAT0160 IMMUNOGENICITY OF BIOSIMILARS FOR THE TREATMENT OF INFLAMMATORY RHEUMATIC DISEASES: A REVIEW FROM CONFIRMATORY CLINICAL TRIALS}

F. Araújo $^{1,2}$, J. Gonçalves ${ }^{3}$, J.E. Fonseca ${ }^{4,5},{ }^{1}$ Rheumatology, Hospital de Sant'Ana, SCML, Cascais; ${ }^{2}$ Institute of Microbiology, Faculdade de Medicina da Universidade de Lisboa, Lisboa; ${ }^{3}$ Med-Research Institute of Medicines, Faculdade de Farmácia da Universidade de Lisboa; ${ }^{4}$ Rheumatology, Hospital de Santa Maria, Lisbon Academic Medical Centre, Lisbon; ${ }^{5}$ Rheumatology Research Unit, Instituto de Medicina Molecular, Faculdade de Medicina, Universidade de Lisboa, Lisboa, Portugal

Background: The assessment of immunogenicity is mandatory during the comparability exercise of biosimilar candidate drugs, as even small structural differences can potentially elicit antidrug antibodies (ADA) and affect efficacy and safety.

Objectives: To review the incidence of ADA and neutralizing ADA (nADA) in confirmatory clinical trials of biosimilar drugs approved for the treatment of inflammatory rheumatic conditions in the European and North-American markets; to review the type of assays used for this purpose; to compare the incidence of ADA with historical data from reference biotechnological drugs.

Methods: We performed a literature search in the Medline database and hand searched EULAR and ACR meeting abstracts to identify phase I and III confirmatory clinical trials of biosimilar drugs for the treatment of rheumatic conditions approved in the European and North-American markets. Open-label extensions involving biological switch were not included. All outcomes regarding immunogenicity were extracted (ADA, nADA and type of immunogenicity assays). Results: We screened 255 articles by title and abstract and 7 publications fulfilled our inclusion criteria. Three meeting abstracts were also included. Six studies assessed infliximab biosimilars (CT-P13 and SB2), three studies assessed etanercept biosimilars (SB4 and GP2015) and one study assessed an adalimumab biosimilar (ABP 501). All but two concerned phase III trials and seven were performed on rheumatoid arthritis patients. All biosimilars had comparable immunogenicity profiles in respect to their reference drugs, except for the etanercept biosimilar SB4, which presented significantly less ADA when compared to reference etanercept $(0.7 \%$ vs $13.1 \%$ at 24 weeks and $1.0 \%$ vs $13.2 \%$ at 52 weeks, $p<0.001$ for both). As expected, infliximab had the highest incidence of ADA; the proportion of ADA in studies of infliximab and adalimumab was higher when compared to historical data. Only 4 studies reported nADA, which were highest in the infliximab biosimilar CT-P13 54-week study in ankylosing spondylitis patients. Electrochemiluminescence immunoassay was the preferred method to measure ADA. Table 1 summarizes the main findings in the included studies.

Table 1. Immunogenicity of biosimilars approved for the treatment of inflammatory rheumatic diseases. ADA: antidrug antibody, NA: not available, nADA: neutralizing antidrug antibody. ${ }^{*} T$ The EGALITY study presented a four-arm design in which two arms were continuously treated with either reference etanercept or GP2015 and the other two arms were systematically switched. The results presented in this table concern the groups continuously treated with reference etanercept or GP2015

\begin{tabular}{|c|c|c|c|c|c|c|}
\hline $\begin{array}{l}\text { Study } \\
\text { population }\end{array}$ & & \begin{tabular}{|l|} 
Reference \\
drug ADA (x)
\end{tabular} & $\begin{array}{l}\text { Reference } \\
\text { drug nADA (x) }\end{array}$ & $\begin{array}{l}\text { Biosimilar } \\
\text { ADA }\end{array}$ & $\begin{array}{l}\text { Biosimilar } \\
\text { nADA (\$) }\end{array}$ & ADA/RADA assoy \\
\hline \multirow{11}{*}{$\begin{array}{l}\text { Rheumatoid } \\
\text { srthritis }\end{array}$} & \multicolumn{6}{|c|}{ C.P13 (Infliximab) } \\
\hline & $\begin{array}{l}\text { YOO } 2013 \\
\text { (PLANETRA, } 30 \mathrm{w} \text { ) }\end{array}$ & 48.2 & NA & 48.4 & NA & $\begin{array}{l}\text { Electrochemiluminescence } \\
\text { immunosssy/NA }\end{array}$ \\
\hline & $\begin{array}{l}\text { Yoo } 2016 \\
\text { (PLANETRA, 54 w) }\end{array}$ & 36.0 & NA & 41.1 & NA & $\begin{array}{l}\text { Electrochemiluminescence } \\
\text { immunoassay/ flow-through } \\
\text { immunoassay }\end{array}$ \\
\hline & \multicolumn{6}{|l|}{ S82 (infliximab) } \\
\hline & Choe 2015 (30 w) & 49.7 & NA & 55.1 & $\mathrm{NA}$ & $\begin{array}{l}\text { Electrochemiluminescence } \\
\text { immunoassay/ competitive ligand- } \\
\text { binding assay }\end{array}$ \\
\hline & Choe $2015(54 \mathrm{w})$ & 57.5 & NA & 62.4 & NA & NA \\
\hline & \multicolumn{6}{|l|}{ SBA (etanercept) } \\
\hline & Emery $2015(24 \mathrm{w})$ & 13.1 & 3 & 0.7 & 0 & $\begin{array}{l}\text { Electrochemiluminescence } \\
\text { immunoassay/ competitive ligand- } \\
\text { binding assoy }\end{array}$ \\
\hline & $\begin{array}{l}\text { Vencovsky } 2015 \\
(52 \mathrm{w})\end{array}$ & 13.2 & NA & 1.0 & NA & NA \\
\hline & \multicolumn{6}{|c|}{ ABP 501 (adalimumab) } \\
\hline & Cohen $2015(24 \mathrm{w})$ & 38.2 & 11.1 & 38.3 & 9.1 & NA \\
\hline \multirow{3}{*}{$\begin{array}{l}\text { Ankylosing } \\
\text { spondyilitis }\end{array}$} & \multicolumn{6}{|c|}{ cr.P13 (infliximab) } \\
\hline & $\begin{array}{l}\text { Park } 2013 \\
\text { (PLANETAS, } 30 \mathrm{w} \text { ) }\end{array}$ & 22.5 & NA & 27.4 & NA & $\begin{array}{l}\text { Electrochemiluminescence } \\
\text { immunoassay/NA }\end{array}$ \\
\hline & $\begin{array}{l}\text { Park 2016 } \\
\text { (PLANETAS, } 54 \text { w) }\end{array}$ & 23.0 & 100 & 19.5 & 100 & $\begin{array}{l}\text { Electrochemiluminescence } \\
\text { immunoassay/ flow-through } \\
\text { immunoassay }\end{array}$ \\
\hline \multirow[t]{2}{*}{ Psoriasis } & \multicolumn{6}{|c|}{ GP2015 (etanercept) } \\
\hline & $\begin{array}{l}\text { Griffiths } 2016 \\
\text { (EGALTY, 52 w)* }\end{array}$ & 2.9 & 0 & 0 & 0 & $\begin{array}{l}\text { Electrochemiluminescence } \\
\text { immunoassay/ competitive ligand. } \\
\text { binding assay }\end{array}$ \\
\hline
\end{tabular}

Conclusions: Currently approved biosimilars for the treatment of rheumatic diseases have comparable immunogenicity profiles in respect to their reference drugs. The discrepancy in ADA between SB4 and reference etanercept did not correlate with efficacy or safety and did not preclude biosimilarity, according to the regulatory agencies. The higher proportion of ADA compared to historical data may be explained by the greater sensitivity of current immunogenicity assays, such as electrochemiluminescence.

Disclosure of Interest: None declared

DOI: 10.1136/annrheumdis-2017-eular.2486 